\title{
Born Dead or Alive? Revisiting the Definition of Stillbirths in Norway
}

\section{By Hilde Leikny Sommerseth}

To cite this article: Sommerseth, H. L. (2021). Born Dead or Alive? Revisiting the Definition of Stillbirths in Norway. Historical Life Course Studies, 10, 96-100. https://doi.org/10.51964/hlcs9575

\section{HISTORICAL LIFE COURSE STUDIES}

Not Like Everybody Else.

Essays in Honor of Kees Mandemakers

VOLUME 10, SPECIAL ISSUE 3

2021

GUEST EDITORS

Hilde Bras

Jan Kok

Richard L. Zijdeman 


\section{HISTORICAL LIFE COURSE STUDIES}

Historical Life Course Studies is the electronic journal of the European Historical Population Samples Network (EHPSNet). The journal is the primary publishing outlet for research involved in the conversion of existing European and nonEuropean large historical demographic databases into a common format, the Intermediate Data Structure, and for studies based on these databases. The journal publishes both methodological and substantive research articles.

\section{Methodological Articles}

This section includes methodological articles that describe all forms of data handling involving large historical databases, including extensive descriptions of new or existing databases, syntax, algorithms and extraction programs. Authors are encouraged to share their syntaxes, applications and other forms of software presented in their article, if pertinent, on the openjournals website.

\section{Research articles}

This section includes substantive articles reporting the results of comparative longitudinal studies that are demographic and historical in nature, and that are based on micro-data from large historical databases.

Historical Life Course Studies is a no-fee double-blind, peer-reviewed open-access journal supported by the European Science Foundation (ESF, http://www.esf.org), the Scientific Research Network of Historical Demography (FWO Flanders, http://www.historicaldemography.be) and the International Institute of Social History Amsterdam (IISH, http://socialhistory.org/). Manuscripts are reviewed by the editors, members of the editorial and scientific boards, and by external reviewers. All journal content is freely available on the internet at https://openjournals.nl/index.php/hlcs.

\section{Co-Editors-In-Chief:}

Paul Puschmann (Radboud University) \& Luciana Quaranta (Lund University)

hislives@kuleuven.be

The European Science Foundation (ESF) provides a platform for its Member Organisations to advance science and explore new directions for research at the European level. Established in 1974 as an independent non-governmental organisation, the ESF currently serves 78 Member Organisations across 30 countries. EHPS-Net is an ESF Research Networking Programme.

The European Historical Population Samples Network (EHPS-net) brings together scholars to create a common format for databases containing non-aggregated information on persons, families and households. The aim is to form an integrated and joint interface between many European and non-European databases to stimulate comparative research on the micro-level.

Visit: http://www.ehps-net.eu.
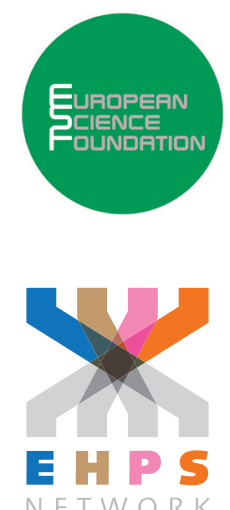


\title{
Born Dead or Alive?
}

\section{Revisiting the Definition of Stillbirths in Norway}

\author{
Hilde Leikny Sommerseth \\ UiT Arctic University of Norway
}

\section{ABSTRACT}

Since 1947 there has been a common understanding among Norwegian historians and demographers that stillbirths registered in the country prior to 1839 included infants who were born alive but died within 24 hours. This paper shows that a revision of this definition is necessary. During the first half of the 19th century, several memoranda, revisions and circulars were distributed by the DanishNorwegian authorities - and Norwegian authorities after 1814 - with the purpose of collecting and then improving the registration of stillbirths. After a close reading of these documents, I find no indication that the ' 24 hours of life' limit was explicitly included in the definition of stillbirths at any time prior to 1839. Instead, 'first day deaths' were given a separate column in the registration forms returned by the priests, midwives and district medical officers who recorded vital events. However, the design of these forms was inconsistent between 1806 and 1831.

Keywords: Stillbirths, Registration practice, Early 19th century, Vital statistics

$\begin{array}{ll}\text { e-ISSN: } & 2352-6343 \\ \text { DOI article: } & \text { https://doi.org/10.51964/hlcs9575 }\end{array}$

The article can be downloaded from here.

\section{(C) 2021, Sommerseth}

This open-access work is licensed under a Creative Commons Attribution 4.0 International License, which permits use, reproduction \& distribution in any medium for non-commercial purposes, provided the original author(s) and source are given credit. See http://creativecommons.org/licenses/. 


\section{INTRODUCTION}

In her seminal 1947 article the demographer Julie Backer concluded that '[...] of particular importance for the statistics was the alteration in 1839 of the classification of stillbirths. [...] only children born without signs of life were to be recorded as stillborn. Before that time, and since 1802, the statistics of stillborn had also included infants born alive, but who had died within 24 hours of birth.' (Backer, 1947, p. 215). Norwegian historians and demographers have used this as the definition of stillbirths in the period prior to 1839 ever since. Consequently, Backer continues, the number of infant deaths recorded in the statistics of that period was understated, while the number of stillbirths was slightly exaggerated. In this essay I wish to argue that a revision of Backer's statement is necessary, contending that none of the circulars giving instructions to the priests, midwives and district medical officers who recorded vital events that were distributed prior to 1839 included text which explicitly included the '24 hours of life' limit in the definition of stillbirths. Indeed, it was made clear that 'first day deaths' were to be recorded in a separate column on the registration forms.

Since the publication of the Lutheran Liturgy on July 25th, 1685 , the Church of Norway ${ }^{1}$ has played a pivotal role in registering the country's baptisms, marriages and burials. The few 'church books', or registers, which survive from the earliest period are characterized by a lack of uniformity. A first attempt to introduce more coherent registration came with a circular published by bishop Hersleb in 1732 which instructed priests to separate their books into three sections; one for baptisms, one for marriages, and one for burials. In 1812 there was a major revision of the registration system. Detailed regulations were announced and printed books for the recording of events were introduced. A further revision was launched in 1820 when, for the first time, the printed books included space for the registration of stillbirths. These were to be recorded in a separate section on the right side of each page in the part of the book recording burials. The 1820 revision remained in place until 1877, when comprehensive church reforms took place. From that point on, stillbirths had their own section in the church book.

WERE PRIEST GIVEN CLEAR INSTRUCTIONS ON HOW THEY SHOULD

\section{REGISTER A STILLBIRTH?}

Although the information was not specifically asked for, priests did register stillbirths in their church books before 1820. At the Domkirken, in the city of Trondheim, the priest drew columns by hand in the church book's burial register covering the years 1783 to 1818, with males on the right-hand side of the book and females on the left. When it came to the registration of stillborn children, only the names of the parents were given and in the 'disease' column the priest wrote 'dødfødt' (stillborn). The age of the deceased was given as zero. Other zero-year-olds are observed but they have 'nyfødt' (newborn) in the disease column; some of these have their name recorded, others do not. After 1820, it may be noted, priests continued to write 'nyfødt' in the burials section of their church books, but instances of 'dødfødt' were relocated to the new stillbirth section. We can assume that the registration of stillbirths became more accurate when the extra columns were introduced in 1820. They would certainly remind the priests to enter the details of a stillbirth whenever they registered a burial. In future research we intend to investigate to what extent the relocation of stillbirths into an independent section also indicated a shift in the way burial rites were conducted. ${ }^{2}$

It is commonly understood that the structure of the church books became increasingly complex as the central authorities' need for statistical information grew and evolved, and these demands might shed some light on why priests also registered stillbirths prior to 1820, and why the church books included specific columns and sections after 1820.

$1 \quad$ Denmark-Norway until 1814.

2 Although the Lutheran church recognized children born without signs of life as God's children, they did not see the necessity of a burial. Theologians reasoned that as the child had not been baptized and thus brought into the church, no ceremony was needed to mark their passing out of the church either (Misje, 2010). 
From December 30th, 1735, just a few years after priests in Norway were first instructed to separate their church books into three sections, they were required to submit an annual summary list of the births and deaths occurring in their parish to the National Chamber of Commerce. Further information was required by a memorandum which was circulated in 1775, along with a pre-printed form on which the annual returns were to be completed. The list of deceased persons had to be provided with their ages categorized into 10-year intervals. There was also a section where 'Peculiarities of those Born and Deceased' could be noted. It is entirely possible that some priests mentioned stillbirths here, especially in cases involving a dramatic outcome for both the mother and child, but it is not clear whether this was done consistently.

In the Age of Enlightenment nations saw the number of their population as a measure of their wealth. In Denmark-Norway, the authorities made reducing the number of stillbirths one of their goals, and we should view the establishment of the field of specialized midwifery in this context. In order to monitor whether their policies were meeting with success, the government circulated several circulars containing revisions of the 1775 registration instructions. In the first of these, dated June 14th, 1800, two columns were added to the form: stillbirths were to be listed separately for males and females. ${ }^{3}$ This circular further specified that all stillbirths that occurred during the first 7 months of pregnancy were to be excluded from the list; these were to be defined as abortions. The new instructions also stipulated that stillbirths were not to be included in any count of live births.

Two years later, on Christmas Eve 1802, another revision appeared. In the introduction, it was clearly stated that the returns made over the last two years had not been satisfactory for the purposes intended. To improve the situation two changes were to be made. First, each midwife was now required by law to report the number of births she had attended where the child either had shown no signs of life or had died within 24 hours of birth to her local priest. ${ }^{4}$ Second, the priest should add the stillbirths reported by the midwives' into the church book, before compiling a summary table which he was to send to the local district medical officer. Each of the 36 medical officers were then to send a final, complete report - with any remarks they wished to make - to the bishop of the diocese. Each bishop, of which there were 5 in Norway, would then create an aggregated table, including stillbirths, and send it to the government.

In the years following 1802, the revisions and circulars that were published repeatedly targeted one group in particular: the midwives. Even in 1802 midwives were being threatened with a fine if they did not report instances of stillbirth. The size of the fine was reduced in 1806, but only for trained midwives working in rural areas. In such areas most deliveries were, in fact, attended by untrained midwifes, but even they, despite their lack of education, were obliged to report stillbirths. In a circular of January 25th, 1806 untrained midwives were threatened with a fine if they did not call for a doctor or midwife when a delivery they were attending developed complications. A memorandum from December 19th, 1807 emphasizes that an untrained midwife in a rural area was legally bound to report to the priest at each Sunday's service if she had attended any stillbirths in the previous week. The same memorandum also noted, however, that, as the role of an untrained midwife was not actually to deliver the baby but to provide care and assistance, she would not be fined if she did not report a stillbirth. This situation changed when a law was passed in 1839. From then on, if an untrained midwife assisted at a difficult delivery without calling for a doctor or a trained midwife, and the newborn and/or the mother came to any harm, she would receive a fine as a warning the first time this happened, but if she repeated the offence she would be sent to prison on bread and water for 5 to 20 days.

Apart from berating midwives, how could the authorities make the reports they received more complete, accurate and harmonized? They introduced more forms! On December 16th, 1806 it was ordered that the priests, midwives and district medical officers should register stillbirths on separate forms. ${ }^{5} \mathrm{~A}$ midwife was to register each still birth she attended on an individual form. She sent all her forms to the local priest, who then entered these, along with the stillbirths he had registered in the church book, onto a single form which he sent to the district medical officer, who aggregated the information he

3 The several memoranda, revisions and circulars mentioned in this article can be accessed through https:// www.rhd.uit.no/kirkebok/instrukser.html.

4 [Enhver Gjordemoder skal, [...], anmelde for Præsten ethvert Barn, ved hvis Fødsel hun har været brugt, og som enten kommer dødt til Verden, eller dør inden 24 Timer efter Fødselen.]

5 Any medical practitioners was also bound to report to the priest, but not on a separate form. 
received from all the priests in the district onto yet another form - adding in any stillbirths which he had attended which had not previously been registered - , and sent it to the bishop.

It should be noted that while midwives had to register whether a child had shown any sign of life at birth and, if so, how long it had lived, this information was not required on the form completed by the priest, yet it reappeared in the district medical officer's aggregated table. On the doctor's form, those children 'born alive, but dying within 24 hours' appeared as a separate category under the heading 'fully developed stillborn'6; indirectly confirming Backer's statement. However, since both the 1802 and 1806 circulars used the phrasing 'either had shown no signs of life or had died within 24 hours of birth', we should not inclusively conclude that the 'born alive' was added into the column of 'total sum of stillborn'. While we can be pretty certain that priests separated first day deaths from true stillbirths cases in their church book, we cannot be so sure whether they were careful only to report the 'born dead' on the forms they sent on to their district medical officer.

The next 25 years passed without further revisions, and we might be forgiven for thinking that the authorities found the returns satisfactory, but apparently this was not the case. On June 18th, 1831 a new circular was distributed, with no less than five printed forms, and a statement to the effect that this was 'an attempt to improve the orderliness, which had not been acceptable in the past'. The form to be used by midwives was unchanged, but on the priests' form a new column appeared in which the information missing from the 1806 form was to be recorded: whether the child had been born with sign of life or had died within 24 hours of delivery. A further intermediary was introduced into the chain of correspondence: priests were to send their forms to their superior, the Dean, who was to make a duplicate copy of each form before forwarding them and any enclosed background material to the district medical officer. Each medical officer was still to be responsible for aggregating the statistics for his district, but with one important difference. While in 1806 the form had included a column for 'lived for some time after birth' in the section for the 'fully developed', this was removed from the equivalent section in 1831 and placed in a separate summary section, where a) the stillborn, and b) those dying within 24 hours were enumerated by sex. Having compiled his aggregated form, the medical officer sent it to his bishop, along with the forms supplied by the dean, the priests and the midwives.

Finally, the bishop was to send a summarized 'general table', covering the whole of his diocese, to the Ministry of Church Affairs and Education. It was probably not a straightforward task for the bishop to rearrange the information he received into a 'general table', as he would have had to alternate between the various forms, some aggregated and others not, containing different headings for the same information. Any potential flaws in his final return to the government could be checked, however, as he was obliged to enclose all relevant background materials.

A preliminary comparison of the background materials with the general tables reveals at least one problem: district medical officers had a tendency to add the number of abortions and 'premature' fetuses into the group which was meant to include only the 'fully developed stillborn'. This suggests that medical officers - along with midwives and priests - found it difficult to distinguish between a fully developed fetus and one that was born prematurely. A revised memorandum sent out on October 16th, 1839 appears to confirm this as the Ministry of Church Affairs and Education acknowledges that this issue was affecting the returns. The solution, however, was not to change any forms, but to give the medical officers an additional month to prepare their tables.

A circular sent out on December 9th, 1842, reduced the number of forms to be used from five to two. We must ask whether this was done solely to reduce the obvious confusion the five forms created for the bishops as they created their general tables, or whether the change was also intended to improve the distinction between 'fully developed' and 'premature' stillborn infants in the registers. The first of the new forms were to be filled out by all midwives, whether trained or untrained, and medical practitioners. These forms were then to be delivered to the local priest. At the end of each quarter, the priest was to compare the forms he had received against the entries in his own church registers, and add information to each form indicating whether the stillborn child were legitimate or illegitimate. He was then to send the forms to the district medical officer who would use the information to fill in the second new form. This required him to indicate the number of abortions, where the fetus was of less than 28 weeks gestation; the number of stillbirths where the fetus was premature, born in weeks 28 to 36 of gestation; and the number who were fully developed, born after week 36 . These three

$6 \quad$ Those resulting from pregnancies of more than 7 months duration. Subsequently the specified period of gestation was fixed more precisely at 28 weeks. 
divisions were further categorized by legitimacy and sex. The table then included a column showing the 'total sum of stillbirths and those dying within 24 hours of birth', before a final column, omitting abortions, summarized the number of those born 'prematurely' and 'fully developed', distinguishing the stillborn from those who had died within 24 hours after birth. The stillborn were further divided into those showing 'signs of decay' and those with 'no signs of decay'. The medical officer wrote out his aggregated table in duplicate, and sent one directly to his bishop. The other he dispatched, along with the individual forms forming the basis of the table, to the Ministry of Church Affairs and Education at the same time as he submitted his annual district medical report.

\section{SUMMARY}

During the first half of the 19th century, several memoranda, revisions and circulars were distributed by the authorities with the purpose of collecting and then improving the registration of stillbirths. After a careful reading of these documents, I find no indication at any point that the definition of stillbirths automatically included those infants who died within 24 hours of their birth, as previously proposed by Backer. On the contrary, each of the forms used by the midwives, priests and district medical officers to record stillbirths included a separate column or section where the person registering the stillbirth had to specify whether the child was born dead or alive. The one exception is the form to be completed by the priests and the district medical officers during the period 1806-1831 where the instructions differed between the midwives and the priests, and between the priests and the medical officers. Consequently, a clear distinction between true stillbirths and 'first day deaths' is more or less impossible to derive from the aggregated tables. However, preliminary findings suggest that the priests reported stillbirths and 'first day deaths' separately in the church books. How, and if, those registering stillbirths were able to distinguish between these two groups, and perhaps more interestingly, how theology and popular religious beliefs may have influenced the registration process and, in turn, any calculations we might wish to make, remain questions for another day.

\section{REFERENCES}

Backer, J. E. (1947). Population statistics and population registration in Norway. Part 1. The vital statistics of Norway: An historical review. Population Studies, 1(2), 212-226. doi: 10.1080/00324728.1947.10415532

Misje, B.-I. (2010). Hvor ble det av mitt barn? En undersøkelse av Kirkens behandling av dødfødte barn i Norge. Kultur- og Kirkedepartementets Olavstipend. Retrieved from https://www.regjeringen. no/globalassets/upload/fad/kirke/hvorbledetavmittbarn.pdf 